\title{
FINANCIAL SECURITY IN THE CONTEXT OF ECONOMICS WELFARE
}

\author{
Robertas VAITKUS (1) 1*, Asta VASILIAUSKAITE் 1 1,2 \\ ${ }^{1}$ Faculty of Public Governance and Business, Mykolas Romeris University, \\ Ateities g. 20, LT-08303 Vilnius, Lithuania \\ ${ }^{2}$ Faculty of Business Management, Vilnius Gediminas Technical Unversity, \\ Saulètekio al. 11, LT-10223 Vilnius, Lithuania
}

Received 28 February 2021; accepted 01 April 2021

\begin{abstract}
Purpose - to describe financial security assurance models and assess the possibilities of using them to solve problems to ensure economics welfare.

Research methodology - analytic, systematic, generalization and comparative methods are used in this article.

Findings - the content of the financial security concept is revealed at the microeconomic and macroeconomic levels, while examining how the selection and implementation of appropriate financial security measures can contribute to sustainable economic prosperity.

Research limitations - the consequences of the implementation of the financial security models analyzed in this article are commented on assessing the peculiarities of one country's national legal system.

Practical implications - appropriate solutions for maintaining financial security provided in the strategies of creating economics welfare can help to decrease social exclusion, risks and negative effects of economic crises.

Originality/Value - in the article was formulated theoretical models of financial security assurance. The use of these models or combinations of models at microeconomic and macroeconomic levels to incorporate financial security instruments allows policy makers to have a universal toolkit in their arsenal. This enables not only to make decisions more quickly, but also to solve the problems of ensuring economics welfare in a more systematic way.
\end{abstract}

Keywords: financial security, sustainable economy, economics welfare, economic policy, risk manangement.

JEL Classification: E60, F50, F52.

Conference topic: Contemporary Issues in Economics Engineering.

\section{Introduction}

Growing social inequalities, various risks, the negative effects of economic crises and other circumstances give priority to issues of economics welfare. The relevance and importance of welfare issues are reflected not only in the scientists research, but also in the guidelines for economic policy-making of individual states and international organizations. Among the United Nations Sustainable Development Goals there is also the goal of promoting the well-being for all at all age groups. The Council of the European Union (2019) noted in its report on Economy of Well-Being that well-being is no longer an interesting sidenote. Rather, it deserves to take a more central place in economic decision-making. This means that authors' Esping-Andersen (1994), Barr (2001), Congleton and Bose (2010), Čiegis and Kozlovskij (2011), Aidukaitè, Bogdanova, and Guogis (2012), Ivaškaitè-Tamošiūnè (2012), Guogis (2014), Ko (2020), Brown, Choi, Coile, and Woodbury (2020), etc., insights on welfare issues become important in solving economic and social problems.

Ko (2020) observes welfare being often conceptilized in socio-economic terms of equity, highlighting distributive issues within growing economies. However, in the face of a coronavirus (COVID-19) pandemic, the challenges of welfare creation are faced with an economic environment that is not conducive to welfare creation. The grinding economic halt and job loss caused by the pandemic has occurred on a scale we have not seen since the Great Depression (Race Forward, 2020). Lopez, Raine, and Budiman (2020) in a study on the effects of coronavirus noted

\footnotetext{
*E-mail: inforobvai@gmail.com
} 
the problems that have emerged as a result of coronovirus - job losses or wage losses, lack of cost reserve in case of emergency, inability to pay the bills for the current month. A study by Litam and Hipolito-Delgado (2021) revealed that the coronavirus pandemic has highlighted the impact of social inequalities and the fact that increasing social inequality can have long-term consequences.

In this context, there is a long-running debate on how to maintain the financial security of households, businesses and the state. Researchers (Porter et al., 2020; Litam \& Hipolito-Delgado, 2021; etc.), organizations and other entities (Federal Trade Commission, Race Forward, McKinsey \& Company; etc.) analyse the economic impact of coronovirus and make suggestions and recommendations that can help in the case of financial difficulties. Operational decisions by states in the adoption of action plans to ensure financial security are needed to minimise the potential negative economic consequences. The international nonprofit organization Aspen Institute (2020) empahasises that the abundance of stakeholders and their interconnectedness lead to policymakers, business leaders, and philanthropy dealing with financial insecurity to take a holistic approach to solving problems. This means that policy makers need to be aware of possible models and instruments for ensuring financial security to implement them. Knowledge of possible models for ensuring financial security, their strengths and weaknesses, facilitates and speeds up decision-making by choosing the most appropriate financial security measures with the greatest economic benefits, both in the short and long term.

There may be a discussion about why financial security needs to be talked about in the context of economics welfare. The theory of the welfare economy examines how economic activity should be managed in order to maximise economics welfare, and what conditions are needed for this. Bergheim (2006) points out that factors that positively affect economics welfare are leisure, wealth, non-market activity, and are negatively influenced by factors such as unemployment and insecurity. Some other authors Abu Bakar, Mohamed Osman, Bachok, Ibrahim, and Zin (2015) also support the opinion that the emergence of welfare is influenced by the satisfaction of basic needs and the provision of certain conditions, including financial security. The Aspen Institute (2020) also links the concept of financial security to financial well-being. Brown et al. (2020) revealed that social security policies have an impact on future financial well-being and financial security. The insights of these authors justify that one of the conditions for economics welfare is financial security.

The links between financial security and welfare means that financial security issues also need to be addressed when dealing with economics welfare. Ahmad and Sabri (2014), Vergun and Topenko (2016), Zwolak (2017), Haber, Bukhtiarova, Chorna, Iastremska, and Bolgar (2018) and other authors represent an opinion that financial security is a multifaceted phenomenon. As a result, financial security is interpreted in different ways and different ways of creating financial security can be used. At the same time, political will, economic and social objectives, available resources and other circumstances also influence the formulation of state policy in the field of financial security. Researchers De Serres, Kobayakawa, Sløk, and Vartia (2006), Langevoort (2010), Schultz, Arndt-Bascle, Davidson, and Gerloff (2019), etc., also suggested a whole range of financial security measures. The overallity of these circumstances leads to the need to assess the different financial security considerations in the course of the development of the economics welfare strategy and to integrate the proposed measures into clearly expressed models to ensure financial security. However, there may be a dilemma in the practical choice of the most appropriate models to reduce financial insecurity. Therefore, in order to solve this problem, it is necessary to focus on the above circumstances and to develop clear models for ensuring financial security, the functioning or coordination of which would make the creation of welfare state strategy sustainable.

Object - financial security assurance models and possibilities for their use.

Purpose - to describe financial security assurance models and assess the possibilities of using them to solve problems to ensure economics welfare.

In order to achieve the goal, the article solves the following tasks:

1. To analyze theoretical approaches to financial security from the microeconomic and macroeconomic aspects.

2. Summarize possible models for ensuring financial security and reveal the possibilities of using these models to address long- and short-term financial security needs at different economic levels.

3. To assess the specificities of the national legal framework in terms of the application of financial security models.

Methodology of research. The research includes analysis and synthesis of research, works, empirical research and other economic literature. Financial security models have been identified and described by systematizing and comparing the opinions and insights of different authors. Taking into account the need to address current and future economics welfare, theoretical and practical (legal) aspects of the integration of financial security models shall be examined. Based on holistic theoretical access, the article describes synergies between financial security models and instruments, and the financial security construct presented focuses on helping policymakers to reduce social exclusion, risks and the negative impact of crises.

In order to solve the challenges set, this article first analyses the content of the concept of financial security from a microeconomic and macroeconomic point of view. It shall then reveal the possible models for ensuring financial security and the objectives pursued, the appropriateness of the model for individual entities and whether the model is designed to address operational or long-term financial insecurity. In particular, the characteristics of the national legal framework of the country concerned in terms of the application of the financial security model are assessed. 


\section{Microeconomic and macroeconomic aspects of financial security}

Financial relations between households, businesses, and government entities are influenced by various political, economic, social, legal, psychological, religious, racial, customary, educational and other circumstances. In addition, various financial reporting tools and mechanisms exist in the financial sector. Karimi (2015) also claims that security elements have economic, social, and political impacts on the surrounding world. Kremen, Shkolnyk, Semenog, and Kremen (2019) pointed out that the financial sector has dynamic characteristics and is influenced by financial and economic policies and the financial market. Boy (2017) emphasises that spectrum of financial security extends to money, moneyness, saving and stores of value in various manifestations of 'safety' defined as the product of successful underwriting. Lankauskienè and Tvaronavičienè (2012) singled out the links of financial security with price stability, security of the existing financial portfolio, security of markets, accumulation for retirement, payment of property taxes. Giriūnienė, Černius, Giriūnas, and Jakunskienè (2019) analyzing the concepts of financial security, made an observations that conceptions of financial security cover both monetary, economic, social, political, and national defense aspects. Reznik, Getmanets, Kovalchuk, Nastyuk, and Andriichenko (2020) noted that the components of the financial security of the state are banking, debt, budget, currency and monetary security.

The authors of Delas, Nosova, and Yafinovych (2015), Siemiątkowski (2017), Sylkin, Kryshtanovych, Zachepa, Bilous, and Krasko (2019) and other authors confirm the importance of financial security as an integral part of the economy. Ahmad and Sabri (2014) proves that financial security exists not just in macro level (company/country) but also micro level (individuals/consumers). Floyd and Croft (2011) have singled out a vertical security range that includes individual, group, state, regional and global levels. Solodovnik (2015) divides economic and financial security into state, region, company, individual industries, individual, society, international community. Blakyta and Ganushchak (2018) consider financial security as part of economic security. Haber et al. (2018) have revealed that financial security is a component of not only economic, but also national security and security of every person. Alifanova and Evlakhova (2017) identified national, regional and household objects in their analysis of financial security.

Based on the authors' insights, financial security can be divided into two levels: horizontal and vertical. The vertical level reflects the place and direction of financial security in terms of the financial sector, the economy, nacional interests and the international level. The horizontal level of financial security reflects the direction of the impact of financial security on entities of different levels (see Figure 1).

As can be seen from Figure 1. financially unfavourable circumstances may arise in different areas of financial management. The sources of adverse circumstances may relate both to the various entities active in the financial field and to the willingness of consumers themselves to show their expenditures above their status or other circumstances. Davydenko (2015) described financial security as a security of financial interests of entities at all levels of financial relations, security of households, enterprises, organizations and institutions, regions, industries and sectors of the state in general with financial resources sufficient to meet their needs and financial obligations. This means that financial security must be of equal importance to all participants in the financial system and must include households, businesses, organizations, institutions, industries, regions, the public sector, etc.

Finanancial security refers to both vertical and horizontal levels, but other details of financial security are possible. Ahmad and Sabri (2014) indicated that benefits of financial security appear a number of areas including spending, savings, retirement planning, credit use, and investment. Financial security can also be broken down according to the time perspective, i.e. whether financial security meets current needs or whether future financial security issues are addressed. Different instruments for ensuring financial security are possible.

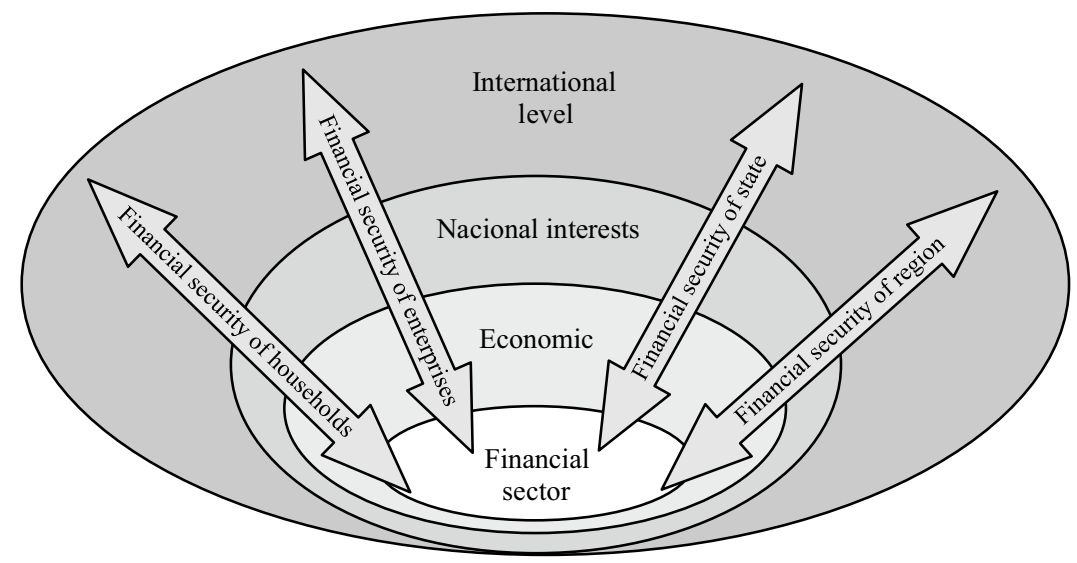

Figure 1. Financial security levels (source: compiled by the authors) 


\section{Financial security instruments}

Karimi (2015) pointed out that elements of economic, state and national security exist in a broader framework and the need a unifying construct that brings the security elements together, is focused on larger, long-term issues, and orients resources to address national issues. Based on Amadae (2017), Franchuk, Omelchuk, Melnyk, Kelman, and Mykytyuk (2020), Delas et al. (2015), it can be said that the choice and implementation of the financial security concept creates opportunities for the growth and stability of the company. This means that addressing financial security as an integral part of economic security requires a cross-cutting approach, not only in financial security models, but also in the tools and instruments to be used to implement them. The selection of instruments necessary to ensure financial security is an important condition for their application and operation at different levels of financial security. As shown by the authors' (De Serres et al., 2006; Amadae, 2017; Schultz et al., 2019; Franchuk et al., 2020; Munyon et al., 2020) research, three groups of instruments necessary to ensure financial security can be distinguished. These are institutional, functional and valuation approach instruments. These theoretical approaches are not only focused on the microeconomic or macroeconomic level, but also address the needs of basic needs (emergency assistance) and future financial security.

Instruments of an institutional nature shall include institutions, norms and rules implementing financial security for households, enterprises, organizations and other entities. The application of instruments of an institutional nature is the definition and implementation of social forms of behavior and of the procedures and rules for the actions and management of economic operators. For example, Schultz et al. (2019) analysed the importance of regulation for economic growth, social welfare and other areas. De Serres et al. (2006) analyzed the importance of regulating the financial system for output and productivity growth. Langevoort (2010), after examining regulatory developments in securities from different countries since the financial crisis, pointed out that international regulation is often limited to the part that includes complex institutional investors.

Functional financial security instruments are focused on the practical application of financial security measures and the management of financial resources and assets. Authors whose ideas for ensuring financial security are based on efficient and sustainable resource management should be considered proponents of a functional approach. For example, in the opinion of Franchuk et al. (2020), the main task of the financial security system is not only to preserve financial resources, but also to create a safe environment for the continuous development of business. Amadae (2017) noted the importance of credible solutions to the security of business. Jarukaitis (2014) drew attention to the need to establish the fundamental principles of the structure of economic relations (legal and institutional) on the basis of which the market economy would function, as well as to ensure their observance.

The valuation approach to financial security instruments is based on the security aspects and the implementation of financial education. This means that in financial decision, priority is given to various behavioral patterns that are related to a person's education and available financial experience, etc. The authors (Howell et al., 2013; Vaitkus \& Vasiliauskaite, 2018; Munyon et al., 2020) of this approach not only reveal that a value aspect or financial education is important to achieve financial security, but also seeks to determine the impact of financial security on psychological health, interpersonal relationships at work, at home, etc. Vaitkus and Vasiliauskaite (2018) described financial security as the relationship of a person's value with the surrounding outside world and the state of that outside world, which, under certain circumstances, allows to take advantage of financial security measures (savings, liquid reserves or insurance) and thus provides an opportunity to protect himself and his family from financial shocks. This state allows the person to feel financially secure, which creates self-confidence, the surrounding environment, provides additional energy.

The importance of values is confirmed by a study by Munyon et al. (2020), which determined the impact of financial security on attitudes to work and stress in it, as well as the consequences for relationships between home and work. Howell et al. (2013) also noted that as economic standing rises, so do individual perceptions of financial security (a safety need), which in turn increases overall life satisfaction.

In summary, financial security is expressed at different levels and in different segments, and financial security measures can be implemented on the basis of institutional, functional and value instruments. Knowledge of financial security levels and financial security instruments alone may not be sufficient for economics welfare. In order to address financial insecurity identified by different sectors expeditiously, certain sets of measures are needed. These toolkits are therefore presented below through models that have formalised structure.

\section{Financial security assurance models}

The formation of financial security models is complicated, whereas financial security is a multifaceted phenomenon. Authors (Hastings et al., 2013; Semjonova, 2016; Hryhoruk et al., 2019; Munyon et al., 2020; etc.) analyzes various aspects of financial security. Munyon et al. (2020) defined financial security as a subjective state that reflects the adequacy and stability of monetary assets relative to liabilities. The 2019 report by the Group of Thirty (G30) states that lifetime financial security is an opportunity to meet essential living expenses and maintain a desired standard of 
living through to the end of life. This means that a financially secure state is one in which a permanent income is created that allows us to maintain a decent standard of living now and in the future. Ahmad, Sabri, Rahim, and Osman (2018) have made some observations that financially insecure circumstances arise when the individual is faced with a higher demand that exceeds the individual financial resources (for example loss of spouse, divorce, disability of spouse). These insights suggest that financial security objectives and financial safeguards must be set in order to avoid the emergence of financially insecure circumstances. These measures enable households to make decisions that can change lives (e.g. investing in the accumulation of wealth). Financial decisions taken can help to ensure financial protection not only in cases of financial disadvantage, but also at a time when all possible sources of income are lost. Financial protection can help prevent a financial downturn and negative consequences.

In order to ensure financial security, it is important not only to realise that financially insecure circumstances may arise, but also to prepare for them in advance. Perhaps that is why Ermakova (2017) describes financial security as such a assurance of the financial system and the development of financial relations and economic processes, which allows the necessary financial conditions for the stable development of the country's socio-economic and financial sector and allows to maintain the fullness and unity of the financial system (including monetary, budgetary, credit, tax and currency systems), successfully overcoming internal and external threats. Financial security by Semjonova (2016) is interpreted as proper arrangements of the state financial system that ensures financial stability, provides integrity of the public finances and neutralizes threats to money stock, budget, taxes, and credits.

An analysis of the scientific literature reveals, that some authors (Hryhoruk et al., 2019; Khrushch et al., 2019; Zaichko, 2020) links financial security to threats and possible consequences. Other authors (Ahmad \& Sabri, 2015; Davydenko, 2015) are of the opinion that only the development of certain preventive measures can ensure financial security and thus guarantee economics welfare. There authors (De Serres et al., 2006; Hastings et al., 2013) who also highlight the importance of financial literacy or make recommendations on the need for an appropriate distribution of information and resources among entities with different powers that operate in the financial field. Based on different views of the authors, four models of ensuring financial security can be designed: (1) a model for countering threats; 2) preventive model; 3) financial literacy model; (4) a model of balance of power, information and allocation of resources (see Figure 2).

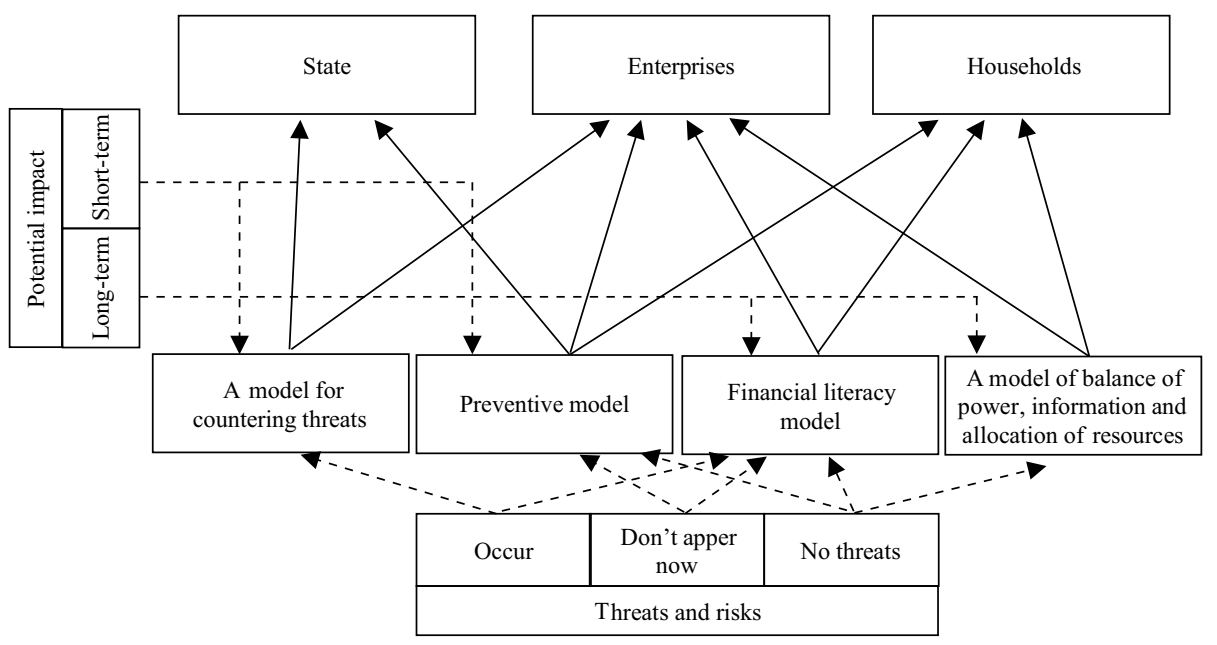

Figure 2. Financial security model management scheme (source: compiled by the authors)

\subsection{A model for countering threats}

The financial security model for countering threats is focused on the identification and response of threats. Effective functioning of financial security as a model for countering threats requires accurate knowledge of financial threats and risks to the state, institutions, organizations and households. Knowing these threats and risks, appropriate financial security measures can be identified that will protect not only threats and risks, but also possible consequences. Zaichko (2020) identified that financial security reflects the state of the financial system and the impact of financial safeguards, especially those of state budgetary policy, to combat existing internal and external threats, and on the direction of risk. In the opinion of Sylkin et al. (2019), the main conditions for ensuring the financial security of the company are not only a high degree of harmony, successful coordination of financial interests, but also the ability to withstand threats to the financial system, which in turn can lead to a crisis. Franchuk et al. (2020) noticed that a timely response to changes in the level of security under threat allows for the timely preparation and implementation of security programs. These programs shall include the consolidation of financial, material, operational, information and other resources, the development of operational actions, strategic decisions, etc. 
In the opinion of Poltorak, Sirenko, Prokopenko, Melnik, and Trusevich (2019), the financial security of the state is a combination of conditions in which the state financial system functions and the impact of internal and external threats does not lead to negative processes in this complex system and does not prevent the creation of favorable financial conditions for its sustainable development. Preparedness for threat protection must have a diverse approach, and according to Davydenko (2015), protection must consist of financial instruments, technologies and services. This must form a whole that is resistant to internal and external negative factors (threats). These conditions and capabilities ensure the protection of national financial interests, adequate provision of financial resources to all entities and residents.

Hryhoruk et al. (2019) identified that enterprises financial security means being able to protect their priority financial interests in relation to potential and real internal and external threats by achieving and maintaining adequate financial stability, solvency and liquidity, and ensuring the financial independence of enterprises. Vergun and Topenko (2016) see enterprises financial security as an integral feature of the enterprise's ability to deal with current and emerging internal and external risks and threats, as well as the ability of the management system to achieve and maintain financial balance, stability, solvency and liquidity in the current and future periods.

The fight against threats can be complicated by the fact that threats by their nature can be both internal and external. Threats can also be both real and implicit. Therefore, Khrushch et al. (2019) noted that financial security is part of banks' economic security, ensuring an adequate level of stability of the financial position, guaranteeing the protection of financial interests in relation to the implementation of development strategies and the objective of achieving competitive positions against external and internal threats.

Having assessed the peculiarities of a model for countering threats, consider well that this model is more suitable for use in cases where prompt solutions are needed to avoid further damage. The measures needed to implement this model must be clearly regulated and have precise requirements and procedures in place to manage known threats and risks. This model focuses on ensuring the financial security of the activities of the state and enterprises. However, the impact of the model taken in these areas also has a positive impact on the financial security of households.

The financial security model for countering threats can only function effectively where financial threats and risks are known. This leads to the fact that the implementation of this model can be inefficient and ineffective in cases where threats or risks are not clear and known. It follows that a financially secure state can be achieved not only by providing protection against threats, but also when they are prepared in advance. In this context, and in order to avoid new threats and risks that may arise, a preventive approach to ensuring financial security is needed.

\subsection{Preventive model}

The preventive model for financial security is distinguished by the fact that regardless of the level of knowledge of threats and risks, it is assumed that negative consequences can occur at any time and must be prepared in advance. Economic development is under way, in which complex preventive measures are implemented to prepare the financial situation in such a way as to avoid the emergence of risks and associated negative consequences. The financial situation prepared with the help of preventive measures makes it possible to maintain financial stability even in the event of an emergency situation. This means accumulating financial reserves, additional sources of income, etc. in order to prepare for possible negative situations such as job losses, illness or other disasters. Ahmad and Sabri (2015) agree with this, arguing that financial security is often linked to the level of savings, a person's ability to cope with an emergency, sufficient financial resources for retirement and access to income.

It should be noted that financial security by Davydenko (2015), ensures the protection of vital and key interests of the state, regions, businesses and individuals in the financial sector from the effects of a wide range of negative factors and achieving enough quantity of financial resources for entities, their balance, financial stability, liquidity, which provide normal existence and development. In the face of critical fluctuations, volatility of market conditions and variability of a market environment, financial security is a basis of profit formation of an entity, provides a cash flow stability and reduces the risk and, consequently, reduces the losses of the enterprise. Ahmad and Sabri (2014) described financial security as the state of having constant income or other resources to maintenance a standard of living now and in the foreseeable future. Poltorak et al. (2019) associated the financial security of the state with favourable financial conditions for the sustainable development of the financial system.

The absence of financial reserves and sources of revenue, together with excessive spending, increases financial vulnerability, which may have a negative impact on future economic prosperity. This is confirmed by Porter, Bowman, and Curry (2020), those who claim that lower incomes and high expenditures relative to income leads to weakened financial resilience in the short term, over the longer term it is likely to reduce an individual's ability to build financial security.

The preventive model for financial security is focused on meeting the long-term financial security needs of stakeholders. This model is applied in cases where threats and risks do not yet exist, but their nature and possible consequences are known. The preventive model provides for the implementation of preventive measures at household, enterprises and state level. One of the most important preventive measures is the accumulation of reserves of financial 
resources. In emergency situations, these accumulated reserves could be used to meet the necessary needs and thus avoid recessions and negative consequences. This means that the model is suitable for meeting both operational and long-term financial security needs. However, preventive measures may not protect against situations where some entities operating in the financial field abuse their knowledge and rights or if entities active in the financial field do not understand the content of financial services.

\subsection{Financial literacy model}

The financial literacy model is equally important for households, enterprises and the state. This is because knowing and being able to manage your financial resources correctly and not losing them can help prevent from emerging financially insecure circumstances. It also helps to make financial decisions and make rational use of available funds so that they are sufficient not only to meet the necessary needs, but also to allow the accumulation of reserves, investment for the future, etc. The totality of financial knowledge and abilities is identified by various scientists and international organizations as financial literacy. The Personal Financial Literacy Coalition, Jump\$tart, defined "financial literacy" in a 1997 study as "the ability to use knowledge and skills to manage one's financial resources effectively for lifetime financial security" (Hastings et al., 2013).

The European Commission's electronic platform for adult learning in Europe "EPALE" defines financial literacy as the set of skills necessary to correctly understand and interpret financial information in order to make good financial decisions (European Commission, 2016). It is a vital skills which gives people the ability to make informed choices when it comes to their money. Good financial literacy means people are able to make better decisions when it comes to saving for their studies and pension or choosing the right mortgage plan for their home. OECD (2018) financial education, consumer protection and financial inclusion are essential ingredients for both the financial empowerment of individuals and the overall stability of financial markets and economies, particularly in the context of the changing pace of technological progress and the advancement of digital financial services.

A number of research has been carried out to assess how the possession of financial knowledge influences the economic decisions taken and whether the available knowledge has a positive impact. However, there are authors who present a different approaches to financial literacy. Here Hastings et al. (2013) analyzed financial literacy studies, criticized it. These opinions reflect the view that there was a lack of any compelling evidence of a positive impact of financial education, but at the same time the authors identified that increasing the financial capacity of the population is a desirable and socially beneficial goal. Despite this approach, Hastings et al. (2013) acknowledge that well-designed and well-implemented financial education initiatives can have an impact.

The financial literacy model is geared towards a long-term perspective of economic activity. The results of this model bring the greatest benefits only when enterprises and households start applying the acquired knowledge in practice. The model is effective both in cases of threat and when consumers seek to improve existing economics welfare. The importance of financial literacy is particularly highlighted in the financial scaling-up of digital financial services and consumers' efforts to make the right financial decisions. Decisions can determine the economics welfare of the future.

\subsection{A model of balance of power, information and allocation of resources}

Preparing financial resources, acquiring financial knowledge or anticipating and protecting against potential risks may not be sufficient to ensure financial security. This is because everyone has different backgrounds, life and financial experience or different understandings of financial security. In addition, in the area of financial services, entities with different powers are faced with the knowledge and information available. De Serres et al. (2006) highlighted the need to strike the right balance between the various stakeholders. This means that the interests of the weaker side must be protected in the area of financial services, as the specific nature of their activities allows some entities to have more information and rights, thus making it easier to manipulate information or resources.

The balance in power, information and resource allocation is important for financial security to prevent social vulnerability. The importance of this model is highlighted in the development of economics welfare. Council of the European Union (2019) defined 'Economy of Well-being' as an economy that: (1) expands the opportunities available to people for upward social mobility and for improving their lives along the dimensions that matter most to them; 2) ensures that these opportunities translate into well-being outcomes for all segments of the population, including those at the bottom of the distribution; 3 ) reduces inequalities; and (4) fosters environmental and social sustainability.

A balance of power, information and resource allocation in the market creates equal conditions for the participation of all households and enterprises in economic activities. Then it is only the skills available, the risks and responsibilities that are assumed that determine what level of economics welfare will be achieved. This means that the existence of threats and risks under balanced conditions cannot affect households and enterprises, as there is a balanced risk-sharing mechanism in the market. There can be no situation where entities use their position for greater powers, information and resources. This can lead to increasing social exclusion and the reduction of economics 
welfare in particularly socially vulnerable sections of society. At national level, imbalances can lead to a greater need for redistribution of resources.

An analysis of the usability of the models identified and described in this paragraph suggests that the significance of the models depends on the influence of different factors. It must be held that, in order to address financial insecurity expeditiously, financial security models must be applied taking into account their potential impact, the objectives pursued and the existence of financially insecure circumstances. It needs to be noted that the resolution of economics welfare, as well as other important social issues, is the prerogative of the state. This means that the integration of financial security models becomes an important factor in the creating or development of economics welfare strategies. Based on the insights of Jarukaitis (2014), the main tool for optimizing economic relations is the improvement of the institutional framework in the context of which these relations are developed. Brück (2004) mentions that one set of policy instruments includes regulation, supervision and coordination while another involves the provision of financial incentives and disincentives, for example through fiscal policy. This is supported by Monkevičius (2011), who said that the main objective of public administration is to meet citizens' expectations of well-being, which are also implemented through legal regulation.

Schultz et al. (2019) confirm that regulation is one of the government's main tools for stimulating economic growth, strengthening social welfare, ensuring inclusion, protecting the environment, responding to new technological challenges and improving overall quality of life. Consequently, the functioning of financial security models must be based primarily on the creation of a certain legal environment. However, the inclusion of a mechanism for the functioning of theoretical models of financial security in the legal framework may be influenced by the specificities of the national legal framework. The legal system of each country has its own peculiarity regarding the existence of political, economic, customary and other circumstances. According to Jarukaitis (2000) findings, it is up to the states to decide on the status of their international obligations under domestic law. Therefore, the study of the definition of the concept of financial security in the context of national legislation is an important step in the development of country-specific strategies for economics welfare.

\section{Financial security model's framework in Lithuanian legal regulation}

In order to assess the peculiarities of the national legal framework in terms of the application of financial security models, one of the countries of the European Union was selected - Lithuania. Lithuania is one of the countries of the European Union, whose political decisions often mention the goal of creating a welfare state, therefore, the assessment of the role of the financial security component in the national legal system becomes relevant.

\subsection{Evaluation model}

The evaluation first selects the legislation to be analysed (legislation at strategic level, laws and by-laws legislation). The legislation dealing with the security aspect was selected for the analysis. The major part of the analyzed legal consists of strategic level legal acts, as the formed strategic provisions influence the preparation of other legal acts. A detailed list of analyzed legal acts is given in Table 1. The selected legislation is assessed in two respects, the first is the application of the financial security model, and secondly, whether financial security is considered to be a factor of economics welfare. The evaluation shall be carried out using a documentary analysis and elements of semantic analysis.

In order to assess legislation in the first aspect (aspect of the application of financial security models), it analyses whether the legislation takes a coherent and systematic approach and provides a clear methodological design for the financial security model or combinations of financial security models. When assessing whether financial security is considered a factor of economics welfare, the legislation finds the terms and their combinations "economic security", "financial security", "welfare", "economics welfare". It is analysed whether the concepts of financial security and economics welfare are defined in the legislation and/or their meaning is clarified. Whether there are clear criteria to be achieved in the financial security situation. It also assesses whether the terms "financial security" and "economics welfare" are used in legislation according to a uniform logical design, i.e. whether "financial security" is presented as a factor in ensuring "economics welfare".

\subsection{Research results}

On the basis of the results of the analysis of the selected legislation, it can be stated that they do not consistently follow any single model of financial security or the concept of designing combinations of them. The legislation also does not define the criteria for assessing financial security. Some legislation (e.g. The National Security Strategy (Lietuvos Respublikos Seimas, No IX-907, 2002)) refers to the term "economic security", but it is not possible to assess from the presented economic security construct whether the legislators consider financial security to be an integral part of economic security. The Law on the Basics of National Security (Seimas of the Republic of Lithuania, No XI-409, 
R. Vaitkus, V. Vasiliauskaite. 2021. Financial security in the context of economics welfare

Table 1. Content of the analysis of Lithuanian legal acts (source: compiled by the authors)

\begin{tabular}{|l|l|c|c|c|}
\hline $\begin{array}{c}\text { Levels of } \\
\text { legislation }\end{array}$ & \multicolumn{1}{|c|}{ Title of the act } & $\begin{array}{c}\text { Economic } \\
\text { security }\end{array}$ & $\begin{array}{c}\text { Financial } \\
\text { security }\end{array}$ & $\begin{array}{c}\text { Welfare / } \\
\text { economics } \\
\text { welfare }\end{array}$ \\
\hline $\begin{array}{l}\text { Legislation } \\
\text { at the } \\
\text { strategic } \\
\text { level }\end{array}$ & $\begin{array}{l}\text { Lithuania's Progress Strategy "Lithuania 2030" (Lietuvos Respublikos Seimas, } \\
\text { No XI-2015, 2012) }\end{array}$ & + & - & $+/+$ \\
\cline { 2 - 5 } & National Security Strategy (Lietuvos Respublikos Seimas, No IX-907, 2002) & + & - & $+/+$ \\
\cline { 2 - 5 } & $\begin{array}{l}\text { National Progress Programme 2014-2020 (Lietuvos Respublikos Vyriausybè, } \\
\text { No 1482, 2012) }\end{array}$ & - & - & $+/-$ \\
\cline { 2 - 5 } & $\begin{array}{l}\text { 2021-2030 National Progress Plan (Lietuvos Respublikos Vyriausybè, } \\
\text { No 998, 2020) }\end{array}$ & + & - & $+/+$ \\
\cline { 2 - 5 } & $\begin{array}{l}\text { National Research Programme "Welfare society" (Lietuvos Respublikos } \\
\text { svietimo ir mokslo ministerija, No V-166, 2015) }\end{array}$ & + & - & $+/+$ \\
\hline \multirow{2}{*}{ Laws } & $\begin{array}{l}\text { Law on the Basics of National Security (Seimas of the Republic of Lithuania, } \\
\text { No XI-409, 2009) }\end{array}$ & - & - & $+/-$ \\
\cline { 2 - 5 } & $\begin{array}{l}\text { Republic of Lithuania Law on Financial Institutions (Seimas of the Republic } \\
\text { of Lithuania, No IX-1068, 2002) }\end{array}$ & - & + & $-/-$ \\
\cline { 2 - 5 } & $\begin{array}{l}\text { Republic of Lithuania Law on Financial Sustainability (Seimas of the } \\
\text { Republic of Lithuania, No XI-393, 2009) }\end{array}$ & - & - & $-/-$ \\
\hline $\begin{array}{l}\text { By-laws } \\
\text { legislation }\end{array}$ & $\begin{array}{l}\text { The financial crisis prevention and management plan (Lietuvos Respublikos } \\
\text { Vyriausybe, No 1253, 2008) }\end{array}$ & - & + & $+/-$ \\
\cline { 2 - 5 } & $\begin{array}{l}\text { Rules for Determining the Levels of Prevention and Management of Financial } \\
\text { Crises of the Bank of Lithuania and for the Exchange of Information } \\
\text { (Lietuvos banko valdyba, No 03-32, 2013) }\end{array}$ & - & + & $-/-$ \\
\hline
\end{tabular}

2009), which lays down the most important provisions for national security, stipulates that the state must create the right conditions for economic growth as a basic condition for ensuring a higher standard of living for the population. However, this law does not distinguish between economic and financial security as an integral part of national security. It also does not provide the goals and objectives or results to be achieved ensuring economic or financial security.

The legislation analysed does not explicitly regulate the rights, obligations and responsibilities of financial entities in the area of financial security under each proposed financial security model. Thus, without entities knowing what requirements and standards apply to them under one or another financial security model, they may not understand which behavioural model they need to choose in a particular situation. As a result, individuals acting under conditions of uncertainty may interpret the same circumstances diferently or even incorrectly. This does not contribute to increasing financial security, since a person, makes a decisions based only on his personal values, at the same time realizes that he will not receive any responsibility for his misbehaviour.

It has been established that Lithuanian legal acts emphasize only certain aspects of ensuring financial security, which are mainly focused only on ensuring the financial security of financial institutions. As an example, the Law on Financial Institutions of the Republic of Lithuania (Seimas of the Republic of Lithuania, No IX-1068, 2002) mentions the security of the activities of a financial institution and the security of the system of financial institutions, however, there is no precise concept of the activity of financial institutions or the security of the system of financial institutions. This Law establishes a set of measures and requirements for the activities of financial institutions or operational risk, liquidity or solvency arrangements. The financial crisis prevention and management plan (Lietuvos Respublikos Vyriausybe, No 1253, 2008) shall specify that the risk factor is a phenomenon, situation, circumstances or conditions that pose a threat to the security and stability of the financial sector. About other financial system participants, households, enterprises, organizations, institutions, industries, public sector, etc. financial security is not mentioned.

It is important to mention these measures which are significant for ensuring financial security: the National Progress Programme 2014-2020 (Lietuvos Respublikos Vyriausybè, No 1482, 2012) provides for the promotion of economic training programmes and initiatives; the introduction of programmes to develop entrepreneurial skills; to increase the interest of the population and their ability to secure future social guarantees for themselves and their families; the creation of a financial reserve to prevent macroeconomic developments, which by their very nature are also relevant to ensuring financial security.

Most of the legislation examined uses the term "welfare", but it is not clear what the co-legislators consider to be "economics welfare". Lithuania's progress strategy "Lithuania 2030" (Lietuvos Respublikos Seimas, No XI2015, 2012) and the National Progress Programme 2014-2020 (Lietuvos Respublikos Vyriausybe், No 1482, 2012) emphasize that the creation of public welfare is an essential goal of Lithuania's progress. However in these and other legal acts security and welfare are presented as separate parts. As a result, there is the impression that they function in isolation from each other. In some cases, security is put above welfare, indicating that national security is at the 
heart of the state's welfare (see National Security Strategy (Lietuvos Respublikos Seimas, No IX-907, 2002)). Such an inappropriate design for the use of terms is chosen despite the fact that the legislation clearly defines the state's obligation to protect welfare from threats, all instruments at its means. That security is put above welfare is particularly evident when it comes to the military security aspect. For example, the National Progress Plan 2021-2030 (Lietuvos Respublikos Vyriausybe, No 998, 2020) states that "only in a safe environment, it is possible to ensure the functioning of a mature democratic constitutional order, sustainable economic development, the protection of human rights and freedoms, and the viability of civil society". The use of such a formulation makes it clear that security is the basis for everything, and everything else is just a means to ensure security.

On the basis of the results of the analysis carried out, it can be said that the Lithuanian legal system does not follow a consistent and systematic approach in the formation of guidelines for ensuring financial security. The legislation analysed does not define the concepts of financial security and economics welfare, nor does it develop clear criteria for the financial security status to be achieved. No clear model or combination of financial security assurance has been developed and methodologically applied. Moreover, financial security is not linked or properly linked to economics welfare on a case-by-case basis, i.e. financial security is not always considered a factor in ensuring economics welfare.

\section{Conclusions}

This article revealed that financial security is an important factor in ensuring economics welfare. Therefore, when solving the problems of economics welfare, especially in the context of the recent challenges, the importance of financial security support solutions is an essential issue. This means that financial security solutions must be integrated into economics welfare strategies.

The research shows that, in the absence of a clear concept of ensuring financial security, there is a risk that the national legal framework will not follow a systemic approach to this phenomenon. This resulted a lack of clarity on the rights, obligations and responsibilities of financial actors at different levels of legislation to ensure financial security at both microeconomic and macroeconomic levels. This may, in the long term, increase the financial vulnerability of part of the entities, which is particularly important in the context of a declining economic development.

In creating economics welfare, it is important that clear conceptual principles for ensuring financial security are established for all, which should include the financial security models and the instruments necessary for their implementation. The instruments to be selected (institutional, functional and of a valuable nature) must focus both on the microeconomic and macroeconomic level and address the needs for emergency assistance and future financial security. Sustainable economics welfare is to be considered to be achieved by combining the following models of ensuring financial security: (1) a model for countering threats; 2) preventive model; 3) financial literacy model; (4) a model of balance of power, information and allocation of resources.

Formulation of possible financial security models and proposed financial security instruments set out in this article could be further developed to support an action-oriented economics welfare strategy. It would also be appropriate to continue the analysis of the application of financial security models in the national legal systems of other states. Compare the results obtained with each other and assess the possibilities of using good national practices in the area of financial security to address the challenges of ensuring economics welfare. In addition, the theoretical analysis of financial security in the context of economics welfare could provide a basis for further empirical research in this area.

\section{Disclosure statement}

We declare that we do not have any competing financial, professional, or personal interests from other parties.

\section{References}

Abu Bakar, A., Mohamed Osman, M. M., Bachok, S., Ibrahim, M., \& Zin, M. (2015). Modelling economic well-being and social well-being for sustainability: A theoretical concept. Procedia Environmental Science, 28, 286-296. https://doi.org/10.1016/j.proenv.2015.07.037

Ahmad, S. Y., \& Sabri, M. F. (2014). Understanding financial security from consumer's perspective: A review of literature. International Journal of Humanities and Social Science, 4(12), 110-117. http://www.ijhssnet.com/journals/Vol_4_No_12_October_2014/13.pdf

Ahmad, S. Y., \& Sabri, M. F. (2015). Financial security of female-headed households: A preliminary study. Asian Journal of Social Sciences \& Humanities, 4(4), 68-77. http://www.ajssh.leena-luna.co.jp/AJSSHPDFs/Vol.4(4)/AJSSH2015(4.4-08).pdf

Ahmad, S. Y., Sabri, M. F., Rahim, H. A., \& Osman, S. (2018). Self-coping mechanizm of single mothers to achieve financial security ir life. International Journal for Studies on Children, Women, Elderly and Disabled, 3, 91-102. http://www.ijcwed.com/wp-content/uploads/2017/11/IJCWED3_28.pdf

Aidukaite, A., Bogdanova, N., \& Guogis, A. (2012). Gerovès valstybès kūrimas Lietuvoje: mitas ar realybè? Vilnius: Lietuvos socialinių tyrimų centras, Vilnius. https://1stc.lt/download/Geroves_valstybes_kurimas_visas.pdf 
Alifanova, E. N., \& Evlakhova, Yu. S. (2017). Developing a system of indicators of national financial security. Finance and Credit, 23(29), 1723-1736. https://doi.org/10.24891/fc.23.29.1723

Amadae, S. M. (2017). Perpetual anarchy: from economic security to financial insecurity. Finance and Society, 3(2), $188-196$. https://doi.org/10.2218/finsoc.v3i2.2578

Barr, N. (2001). The welfare state as piggy bank: Information, risk, uncertainty, and the role of the state. Oxford University Press. https://doi.org/10.1093/0199246599.001.0001

Bergheim, S. (2006). Measures of well-being. There is more to it it than GDP. Deutsche Bank Research. https://zgf-fortschritt.de/ media/pages/studien/bip-allein-macht-nicht-glucklich/4223390962-1598272078/bergheim-2006-measures_of_well-being.pdf

Blakyta, G., \& Ganushchak, T. (2018). Enterprise financial security as a component of the economic security of the state. Investment Management and Financial Innovations, 15(2), 248-256. https://doi.org/10.21511/imfi.15(2).2018.22

Boy, N. (2017). Finance-security: Where to go? Finance and Society, 3(2), 208-215. https://doi.org/10.2218/finsoc.v3i2.2580

Brown, J., Choi, J., Coile, C., \& Woodbury, R. (2020). Social security and financial security at older ages. Social Security Bulletin, 80(1), 31-40. https://ssrn.com/abstract=3537057

Brück, T. (2004). An economic analysis of security policies (DIW Discussion Papers, No. 456). Deutsches Institut für Wirtschaftsforschung (DIW), Berlin. https://www.econstor.eu/bitstream/10419/18308/1/dp456.pdf

Congleton, R. D., \& Bose, F. (2010). The rise of the modern welfare state, ideology, institutions and income security: Analysis and evidence. Public Choice, 144, 535-555. https://doi.org/10.1007/s11127-010-9673-y

Council of the European Union. (2019). The economy of well-being. (Background Paper (10414/19 ADD 1). OECD. https://data.consilium.europa.eu/doc/document/ST-10414-2019-ADD-1/en/pdf

Čiegis, R., \& Kozlovskij, V. (2011). Ekonominès gerovès matavimo makroekonominių rodiklių sistema. Management Theory and Studies for Rural Business and Infrastructure Development, 3(27), 58-65.

Davydenko, N. M. (2015). Genesis of enterprise financial security. Economic Processes Management: International Scientific E-Journal, (2). https://essuir.sumdu.edu.ua/bitstream/123456789/40296/1/Davydenko.pdf

De Serres, A., Kobayakawa, S., Sløk, T., \& Vartia, L. (2006). Regulation of financial systems and economic growth in OECD countries: An empirical analysis. OECD Journal: Economic Studies, 43, 77-113. https://www.oecd-ilibrary.org/economics/oecd-economic-studies_16097491

Delas, V., Nosova, E., \& Yafinovych, O. (2015). Financial security of enterprises. Procedia Economics and Finance, 27, $248-266$. https://doi.org/10.1016/S2212-5671(15)00998-3

Ermakova, E. P. (2017). Scientific approaches to defining the concept of financial security. Source: National interests Priorities \& Security, 13(9), 1712-1730. https://doi.org/10.24891/ni.13.9.1712

Esping-Andersen, G. (1994). After the golden age: The future of the welfare state in the new global order. Geneva, United Nations Research Institute for Social Development (UNRISD). https://www.unrisd.org/80256B3C005BCCF9/(httpAuxPages)/D93F019CFA85A04280256B650041F3F5/\$file/OPWSSD7.pdf

European Commission. (2016, May 27). EPALE focus: Financial literacy. https://epale.ec.europa.eu/en/blog/epale-focus-financial-literacy

Floyd, R., \& Croft, S. (2011). European non-traditional security theory: From theory to practise. Geopolitics, History, and International Relations, 3(2), 152-179. http://wrap.warwick.ac.uk/48000/

Franchuk, V., Omelchuk, O., Melnyk, S., Kelman, M., \& Mykytyuk, O. (2020). Identification the ways of counteraction of the threats to the financial security of high-tech enterprises. Business: Theory and Practice, 21(1), 1-9. https://doi.org/10.3846/btp.2020.11215

Giriūnienè, G., Černius, G., Giriūnas, L., \& Jakunskienè, E. (2019). Research on the relation between conceptions of the state's economic and financial security: Theoretical aspect. Journal of Security and Sustainability Issues, 8(4), 609-616.

Group of Thirty. (2019). Fixing the pensions crisis: Ensuring lifetime financial security. https://group30.org/images/uploads/publications/G30_Pensions.pdf

Guogis, A. (2014). Kai kurie socialiniai-politiniai gerovès valstybių kūrimo Europoje ir Lietuvoje aspektai. Filosofija. Sociologija, 25(2), 71-79. http://mokslozurnalai.lmaleidykla.lt/filosofijasociologija/2014/2/6976

Haber, J. A., Bukhtiarova, A., Chorna, S., Iastremska, O., \& Bolgar, T. (2018). Forecasting the level of financial security of the country (on the example of Ukraine). Investment Management and Financial Innovations, 15(3), 304-317. https://doi.org/10.21511/imfi.15(3).2018.25

Hastings, J. S., Madrian, B. C., \& Skimmyhorn, W. L. (2013). Financial literacy, financial education and economic outomes. Annual Review of Economics, 5, 347-373. https://doi.org/10.1146/annurev-economics-082312-125807

Howell, R. T., Kurai, M., \& Tam, L. (2013). Money buys financial security and psychological need satisfaction: Testing need theory in affluence. Social Indicators Research, 110(1), 17-29. http://dx.doi.org/10.1007/s11205-010-9774-5

Hryhoruk, P., Khrushch, N., \& Grygoruk, S. (2019). Model for assessment of the financial security level of the enterprise based of the desirability scale. In The $8^{\text {th }}$ International Conference on Monitoring, Modeling \& Management of Emergent Economy (M3E2 2019), 65, 03005. https://doi.org/10.1051/shsconf/20196503005

Ivaškaitė-Tamošiūnè, V. (2012). Perskirstymas gerovès valstybės kilmès teorijose. Socialinè Teorija, Empirija, Politika ir Praktika, 6, 64-73. https://doi.org/10.15388/STEPP.2012.0.1858

Jarukaitis, I. (2000). Europos Bendrijų teisès viršenybė ir valstybių narių bei Lietuvos Respublikos teisè. Teise், 37, 44-63. https://www.lituanistika.lt/content/40456

Jarukaitis, I. (2014). Europos Sajungos ekonominè konstitucija kaip papildoma Lietuvos Respublikos Konstitucijos dimensija: tyrimų kontūrai. Teisés problemos, 2(84), 26-99. https://teise.org/wp-content/uploads/2016/07/Jarukaitis-14-2.pdf

Karimi, B. (2015). Security and prosperity: Reexamining the connection between economic, homeland and national security. https://www.hsaj.org/articles/8069 
Khrushch, N., Hryhoruk, P., Prystupa, L., \& Vahanova, L. (2019). Assessing bank financial security level using the comprehensive index technology. In Advances in Economics, Business and Management Research: Vol. 95. Proceedings of the $6^{\text {th }}$ International Conference on Strategies, Models and Technologies of Economic Systems Management (SMTESM 2019) (pp. 414-419). Atlantis Press. https://doi.org/10.2991/smtesm-19.2019.81

Ko, H. (2020). Measuring fiscal sustainability in the welfare state: Fiscal space as fiscal sustainability. International Economics and Economic Policy, 17, 531-554. https://doi.org/10.1007/s10368-019-00453-2

Kremen, V., Shkolnyk, I., Semenog, A., \& Kremen, O. (2019). Evaluating the relationship between financial sustainability and socio-economic development of countries. Central European Economic Journal, 6(53), 25-38. https://doi.org/10.2478/ceej-2019-0003

Langevoort, D. C. (2010). Global securities regulation after the financial crisis. Journal of International Economic Law, 13(3), 799-815. https://doi.org/10.1093/jiel/jgq032

Lankauskienè, T., \& Tvaronavičienè, M. (2012). Security and sustainable development: Approaches and dimensions in the globalization context. Journal of Security and Sustainability Issues, 1(4), 287-297.

Litam, S. D., \& Hipolito-Delgado, C. P. (2021). When being "essential" illuminates disparities: Counseling clients affected by COVID-19. Journal of Counseling \& Development, 99(1), 3-10. https://doi.org/10.1002/jcad.12349

Lietuvos banko valdyba. (2013). Nutarimas dèl finansiniu kriziu prevencijos ir valdymo pakopu nustatymo bei keitimosi informacija taisykliu patvirtinimo. $2013 \mathrm{~m}$. vasario $21 \mathrm{~d}$. Nr. 03-32. https://www.e-tar.lt/portal/lt/legalAct/TAR.C46D949B7CF7

Lietuvos Respublikos Seimas. (2002). Nutarimas dèl Nacionalinio saugumo strategijos patvirtinimo. 2002 m. gegužès 28 d. Nr. IX-907. https://e-seimas.lrs.lt/portal/legalAct/lt/TAD/TAIS.167925?jfwid=rivwzvpvg

Lietuvos Respublikos Seimas. (2012). Nutarimas dèl Valstybès pažangos strategijos „Lietuvos pažangos strategija „Lietuva 2030“ patvirtinimo. 2012 m. gegužès 15 d. Nr. XI-2015. https://e-seimas.lrs.lt/portal/legalAct/lt/TAD/TAIS.425517

Lietuvos Respublikos švietimo ir mokslo ministerija. (2015). Isakymas dèl Nacionalinès mokslo programos „, Gerovés visuomene“ “ patvirtinimo. $2015 \mathrm{~m}$. kovo $2 \mathrm{~d}$. Nr. V-166. https://e-seimas.lrs.lt/portal/legalAct/lt/TAD/c09e5030c1 f011e48799bc57840226ce?jfwid=

Lietuvos Respublikos Vyriausybè. (2008). Nutarimas dèl finansiniu kriziu prevencijos ir valdymo plano patvirtinimo. $2008 \mathrm{~m}$. lapkričio 24 d. Nr. 1253. https://e-seimas.lrs.lt/portal/legalAct/lt/TAD/TAIS.332334/wFbjKanpHA

Lietuvos Respublikos Vyriausybè. (2012). Nutarimas dèl 2014-2020 metų Nacionalinès pažangos programos patvirtinimo. $2012 \mathrm{~m}$. lapkričio 28 d. Nr. 1482. https://e-seimas.lrs.lt/portal/legalAct/lt/TAD/TAIS.439028

Lietuvos Respublikos Vyriausybè. (2020). Nutarimas dèl 2021-2030 metu nacionalinio pažangos plano patvirtinimo. $2020 \mathrm{~m}$. rugsejjo 9 d. Nr. 998. TAR, 2020-09-16, Nr. 19293. https://e-seimas.lrs.lt/portal/legalAct/lt/TAD/c1259440f7dd11eab72ddb4a109da1b5?jfwid=-whxwii77y

Lopez, M. H., Raine, L., \& Budiman, A. (2020, May 5). Financial and health impacts of COVID-19 vary widely by race and ethnicity. Pew Research Center. https://www.pewresearch.org/fact-tank/2020/05/05/financial-and-health-impacts-of-covid-19vary-widely-by-race-and-ethnicity/

Monkevičius, A. (2011). Laimès koncepcija viešosios politikos ideologijoje ir praktikoje. Viešoji politika ir administravimas, 10(4), 534-547. https://repository.mruni.eu/bitstream/handle/007/11098/876-1629-1-SM.pdf?sequence=2\&isAllowed=y

Munyon, T. P., Carnes, A. M., Lyons, L. M., \& Zettler, I. (2020). All about the money? Exploring antecedents and consequences for a brief measure of perceived financial security. Journal of Occupational Health Psychology, 25(3), 159-175. https://doi.org/10.1037/ocp0000162

OECD. (2018). Financial inclusion and consumer empowerment in Southeast Asia. Organisation for Economic Co-operation and Development. https://www.oecd.org/daf/fin/financial-education/Financial-inclusion-and-consumer-empowerment-in-Southeast-Asia.pdf

Poltorak, A., Sirenko, N., Prokopenko, N., Melnik, O., \& Trusevich, I. (2019). Behavioral approach to monitoring the state of national financial security. Management Theory and Studies for Rural Business and Infrastructure Development, 41(1), $102-113$. https://doi.org/10.15544/mts.2019.10

Porter, E., Bowman, D., \& Curry, M. (2020). All in it together? Financial wellbeing before COVID-19. Brotherhood of St. Laurence. https://www.bsl.org.au/research/publications/all-in-it-together/

Race Forward for the Zero Cities Project. (2020). Impacts of Covid 19 addendum to the racial equity assessment tool. https://www.usdn.org/uploads/cms/documents/final_raceforward_impactsofcovid19_cc.pdf

Reznik, O., Getmanets, O., Kovalchuk, A., Nastyuk, V., \& Andriichenko, N. (2020). Financial security of the state. Journal of Security and Sustainability Issues, 9(3), 843-852. https://doi.org/10.9770/jssi.2020.9.3(10)

Schultz, R., Arndt-Bascle, C., Davidson, P., \& Gerloff, B. (2019). Better indicators for better regulation: The OECD iREG experience. Revista de Economica ICE, 907, 51-68. http://www.oecd.org/gov/regulatory-policy/Better-indicators-for-better-regulation.pdf

Seimas of the Republic of Lithuania. (2002). Republic of Lithuania law on financial institutions. 10 September 2002, No IX1068. https:/e-seimas.lrs.lt/portal/legalActPrint/lt?jfwid=f4nne5s3y\&documentId=996f5e80483811e68f45bcf65e0a17ee\&category $=\mathrm{TAD}$

Seimas of the Republic of Lithuania. (2009). Law on the basics of national security. 19 December 1996 No VIII-49. https://eseimas.1rs.1t/portal/legalAct/lt/TAD/TAIS.353942?jfwid=pd6eq4zc3

Seimas of the Republic of Lithuania. (2009). Republic of Lithuania law on financial sustainability. July 22nd, 2009 , No XI-393. https://e-seimas.lrs.lt/portal/legalAct/lt/TAD/ebaeb54248fd11e68f45bcf65e0a17ee?jfwid=16rzjwisdc

Semjonova, N. (2016). Financial security in the Baltic States: Comparison with selected EU countries. Economics and Business, 29(1), 90-95. https://doi.org/10.1515/eb-2016-0026 
Siemiątkowski, P. (2017). External financial security of the European Union member states outside the Eurozone. Journal of International Studies, 10(4), 84-95. https://doi.org/10.14254/2071-8330.2017/10-4/6

Solodovnik, O. O. (2015). Financial and economic security of the public-private partnership: Theoretical and methodological framework. Problems of Economy, 1, 133-138. http:/oaji.net/articles/2015/728-1437467343.pdf

Sylkin, O., Kryshtanovych, M., Zachepa, A., Bilous, S., \& Krasko, A. (2019). Modeling the process of applying anti-crisis management in the system of ensuring financial security of the enterprise. Business: Theory and Practice, 20, 446-455. https://doi.org/10.3846/btp.2019.41

The Aspen Institute. (2020). The state of financial security 2020: A framework for recovery and resilience. https://www.aspeninstitute.org/publications/the-state-of-financial-security-2020-framework/

Vaitkus, R., \& Vasiliauskaite, A. (2018). A valuable aspect of the concept of financial security. Public Security and Public Order: Scientific Articles, 20, 313-325. https://repository.mruni.eu/bitstream/handle/007/15264/Vaitkus_2018_VSVT.pdf?sequence $=1 \&$ isAllowed $=\mathrm{y}$

Vergun, A., \& Topenko, Y. A. (2016). Evolution of views on financial security as a management unit. Економіка: реалї часу, 4(26), 122-134. https://economics.opu.ua/files/archive/2016/No4/122.pdf

Zaichko, I. V. (2020). Methodical provision of financial security assessment of the state. Economies' Horizons, 1(12), 15-25.

Zwolak, J. (2017). The financial security of smalland medium-sized enterprises in Poland. Ekonomski Pregled, 68(4), $399-412$. https://hrcak.srce.hr/187556 